\title{
INVESTIGATION OF THE MECHANICAL PROPERTIES OF A SQUEEZE-CAST LM6 ALUMINIUM ALLOY REINFORCED WITH A ZINC-COATED STEEL-WIRE MESH
}

\author{
DOLOČEVANJE MEHANSKIH LASTNOSTI LIVARSKIH Al-ZLITIN \\ LM6, OJAČANIH S POCINKANO JEKLENO MREŽO
}

\author{
Samson Jerold Samuel Chelladurai ${ }^{1}$, Ramesh Arthanari $^{2}$, Kirubaharan Krishnamoorthy ${ }^{1}$, \\ Kamal Shankar Selvaraj ${ }^{1}$, Prabu Govindan ${ }^{1}$ \\ ${ }^{1}$ Sri Krishna College of Engineering and Technology, Department of Mechanical Engineering, Coimbatore 641008, India \\ ${ }^{2}$ Sri Krishna College of Technology, Department of Mechanical Engineering, Coimbatore 641042, India \\ samsonjeroldsamuel@skcet.ac.in
}

Prejem rokopisa - received: 2017-02-06; sprejem za objavo - accepted for publication: 2017-09-22

doi:10.17222/mit.2017.019

Composites of an LM6 aluminium alloy reinforced with a zinc-coated steel-wire mesh were prepared with squeeze casting. Three different orientations of $0^{\circ}, 45^{\circ}$ and $90^{\circ}$ of the zinc-coated steel-wire mesh were used with the aluminium alloy. The microstructures of the castings were analysed and the hardness, tensile strength and ductility were investigated. The fracture surfaces of the matrix and the composites were examined using a field-emission scanning electron microscope (FESEM). The results revealed that the hardness of the composites increased compared to the matrix. Also, the tensile strength of the composites increased with the increasing angle of orientation. The tensile strength increased by up to $11 \%$ for the composite with a steel-wire mesh at the $90^{\circ}$ orientation. However, the ductility of the composites decreased due to the presence of micropores at the interface of aluminium and the steel-wire mesh. Micrographs of fracture surfaces showed a dimple formation in the matrix and a wire pull-out; a broken wire was observed in the composites.

Keywords: aluminium alloy, steel-wire mesh, squeeze casting, mechanical properties

V članku avtorji opisujejo izdelavo kompozitov s kovinsko osnovo iz LM6 Al zlitine, ki so ojačani z mrežo iz pocinkane jeklene žice. Kompozite so pripravljali s postopkom tlačnega litja v testastem stanju (angl.: squeeze casting). Uporabili so tri različne orientacije pocinkane jeklene mreže $\left(0^{\circ}, 45^{\circ}\right.$ in $\left.90^{\circ}\right)$ za ojačitev matrice iz Al zlitine LM6. Analizirali so mikrostrukture ulitkov in določili njihove mehanske lastnosti, to so: trdota, natezna trdnost in duktilnost. Prelomne površine matrice in kompozitov so pregledali pod vrstičnim elektronskim mikroskopom na poljsko emisijo (FESEM). Rezultati raziskav so pokazali, da se je trdota kompozitov povečala $\mathrm{v}$ primerjavi s trdoto kovinske matrice. Prav tako se je natezna trdnost kompozitov povečevala $z$ naraščajočim kotom orientacije ojačitve. Pri $90^{\circ}$ orientaciji je bila natezna trdnost večja do $11 \%$. Vendar pa se je duktilnost zmanjšala zaradi prisotnosti mikropor na mejah med Al matrico in jekleno mrežo. Mikroskopski posnetki kažejo jamičasto prelomno površino kovinske matrice in izvlek pretrgane žice $\mathrm{v}$ kompozitih.

Ključne besede: zlitina na osnovi Al, mreža iz pocinkane jeklene žice, ulivanje s stiskanjem, mehanske lastnosti

\section{INTRODUCTION}

Aluminium-based metal-matrix composites have been used as lightweight structures in the aerospace, transportation, communication and manufacturing industries because of their excellent strength-to-density and stiffness-to-density ratios. ${ }^{1-9}$ The most commonly used reinforcement in the form of particles, whiskers and fibres increases the mechanical properties and wear resistance of these composites. However, it also decreases the ductility of the composites. ${ }^{10-17}$ Fiber-reinforced composites have distinct advantages over particulate reinforcement. In structural applications, the matrix transmits the load to the fibers and in this way the composite offers a high tensile strength. ${ }^{18}$

Aluminium-matrix composite materials have been prepared by various processes such as powder metallurgy, diffusion bonding, spray co-deposition, in-situ solidification and casting. Out of these, casting is the most economical, viable and simple method to produce components. ${ }^{17}$ Squeeze casting is the preferred casting technique as it produces quality castings with a good surface finish and a near-net-shaped component with minimal post-processing operations, porosity and shrinkage. In this technique a metered quantity of molten metal is poured into a preheated die cavity, then the squeeze pressure is applied to the liquid metal until solidification. ${ }^{20-26}$

In the present work, a steel wire mesh has been selected because of its high strength and elastic modulus. Several authors ${ }^{27,28}$ have investigated the stainless-steelwire/steel preforms reinforced in an aluminium matrix using the squeeze-casting process. R. B. Bhagat ${ }^{28}$ experimented with the reinforcement of stainless-steel wires in aluminium-fabricated components using the squeezecasting process and investigated the effect of volume $\%$ reinforcement on the mechanical properties of composites. The 304-type stainless steel of $0.3 \mathrm{~mm}$ in diameter was used as the reinforcement and the volume fraction was varied up to $40 \%$. The results showed that the 


\section{S. J. S. CHELLADURAI et al.: INVESTIGATION OF THE MECHANICAL PROPERTIES OF A SQUEEZE-CAST LM6 ...}

reinforcement of stainless-steel wires significantly improved the tensile strength of the composites. The tensile strength of the composites increased with an increasing volume of stainless-steel wires in the matrix. However, the actual tensile strength was lower than the predicted tensile strength calculated using the rule of mixture. The interface bonding between the fiber and the matrix was inadequate and that caused fiber pullout during the tensile test. Several intermetallic iron-aluminides compounds such as $\mathrm{Fe}_{3} \mathrm{Al}, \mathrm{FeAl}, \mathrm{Fe}_{2} \mathrm{Al}_{5}, \mathrm{FeAl}_{2}$, $\mathrm{FeAl}_{3}$, and $\mathrm{Fe}_{2} \mathrm{Al}_{7}$ were observed at the interface of the matrix and the reinforcement. Composites with a $40 \%$ volume fraction of stainless-steel wires offered tensile strengths more than three times that of the aluminium matrix.

R. Baron et al. ${ }^{27}$ discussed the effect of mechanical properties on steel and stainless-steel preform-reinforced aluminium composites prepared using the squeezecasting process. A low-density power-metallurgy preform was used as the reinforcement. The microstructure of the composites revealed the presence of an aluminium and iron reaction phase around the metallic preform. The application of a load during the tensile test promoted premature failure by crack initiation at the interface of the matrix and the reinforcement. Stainless-steel preform-reinforced composites offered better mechanical properties over monolithic aluminium and steel preform-reinforced composites. Also, the ductility of the composites decreased with an increasing volume fraction of the reaction phase.

Coating on the reinforcement improves the interface bonding between the reinforcement and the matrix, wetting that in turn increases the mechanical properties of the composites. ${ }^{29-39}$ Several researchers have extensively studied the effect of coating on a steel-fiber reinforcement in an aluminium alloy. D. Mandal et al. ${ }^{39}$ investigated the mechanical properties of copper, nickel and uncoated short steel fibers reinforcement in aluminium produced by the stir-casting process. The electroless deposition method was used to prepare a copper and nickel coating on reinforcements. 500-800 $\mu \mathrm{m}$ length and $80-120 \mu \mathrm{m}$ diameter of steel fibers were used as the reinforcement and $5 \%$ of mass fractions of steel fibers were reinforced in aluminium. The results revealed that the addition of steel fibers significantly improved the mechanical properties of the composites compared to the matrix. The density, hardness, yield strength and ultimate tensile strength of the composite increased by reinforcing $5 \%$ of mass fractions of steel fibers in the matrix. However, the addition of steel fibers decreased the ductility and increased the percentage of porosity in the castings. Copper-coated steel-fiber-reinforced composites exhibited better mechanical properties than the aluminium matrix, aluminium reinforced with nickel and uncoated steel-fiber composites. The fracture surface of the matrix showed dimple formation, which resulted in ductile fracture and fiber pull out, with dimples being observed in the composites. The coppercoated steel-fiber-reinforced composite showed dimples on the surface and coalesced rather than fiber pull out. This was attributed to the better interface bonding between the matrix and the reinforcement.

V. V. Ganesh et al. ${ }^{40}$ investigated the mechanical properties of AA1050 aluminium alloy reinforced with galvanized iron wires. Some $2.5 \%$ of the volume fractions of zinc coated galvanised iron wire with $0.8 \mathrm{~mm}$ diameter was reinforced in aluminium processed using casting process followed by hot extrusion. The results revealed that the composites exhibited better mechanical properties than the monolithic alloy. Micrographs of the composite revealed good interface bonding between the aluminium and the iron wires. The reinforcement of zinc-coated galvanised iron wires in aluminium increased the density, hardness, elastic modulus, yield strength and tensile strength. However, the ductility and coefficient of thermal expansion decreased with an increasing volume fractions of galvanized wires reinforcement.

It has been observed that very few studies have been carried out on aluminium alloy with steel wire mesh reinforcement. In this present work, zinc-coated steel-wire mesh was reinforced in LM6 aluminium alloy by the squeeze-casting process. The microstructure, hardness, tensile strength and ductility of composites were analysed and the fractured surface of a tensile specimen was examined using FESEM. The main objective of this paper is to investigate the mechanical properties of a squeeze-cast LM6 aluminium alloy reinforced with zinc-coated steel wire mesh at various angles of orientation.

\section{EXPERIMENTAL PART}

Commercially available zinc-coated steel-wire mesh with a chemical composition as given in Table 1, with a diameter of $304 \mu \mathrm{m}$, longitudinal and transverse distance

Table 1: Chemical composition of zinc-coated steel-wire mesh, in mass fractions $(w / \%)$

\begin{tabular}{|c|c|c|c|c|c|c|c|c|c|c|}
\hline Sample & $\mathrm{C}$ & $\mathrm{Si}$ & $\mathrm{Cr}$ & $\mathrm{Mn}$ & $\mathrm{Ni}$ & $\mathrm{S}$ & $\mathrm{P}$ & $\mathrm{Cu}$ & $\mathrm{Zn}$ & $\mathrm{Fe}$ \\
\hline $\mathrm{ZnFe}$ & 0.072 & 0.10 & 0.128 & 0.30 & 0.114 & 0.012 & 0.009 & 0.062 & 31.98 & Bal \\
\hline
\end{tabular}

Table 2: Chemical composition of LM6 aluminium alloy, in mass fractions ( $w / \%)$

\begin{tabular}{|c|c|c|c|c|c|c|c|c|c|c|c|}
\hline Sample & $\mathrm{Si}$ & $\mathrm{Fe}$ & $\mathrm{Cu}$ & $\mathrm{Mn}$ & $\mathrm{Mg}$ & $\mathrm{Ni}$ & $\mathrm{Sn}$ & $\mathrm{Pb}$ & $\mathrm{Zn}$ & $\mathrm{Ti}$ & $\mathrm{Al}$ \\
\hline LM6 & 11.78 & 0.40 & 0.02 & 0.02 & 0.03 & 0.006 & 0.05 & 0.06 & 0.12 & 0.08 & $\mathrm{Bal}$ \\
\hline
\end{tabular}



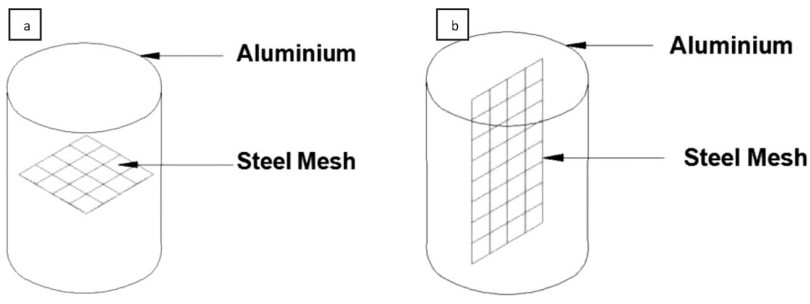

Figure 1: Schematic diagram of steel-wire mesh at various orientations in the aluminium-alloy casting: a) steel-wire mesh at $0^{\circ}$, b) steel-wire mesh at $90^{\circ}$

between the steel wires of $1590 \mu \mathrm{m}$, was used for the reinforcement. Steel-wire mesh was placed inside a preheated die at various orientations of $(0,45 \text { and } 90)^{\circ}$. The schematic diagram of the steel-wire-mesh reinforcement of the aluminium alloy is shown in Figure 1.

A modified universal testing machine with a 40-tonne capacity, as shown in Figure 2, was used for conducting the experiments. The die and punch were made of the SG400 spheroidal graphite iron and EN8 steel, respectively. A ceramic electric heater with a capacity of $400{ }^{\circ} \mathrm{C}$ was used to preheat the die. An electric induction furnace with a $5-\mathrm{kg}$ capacity was used to melt the LM6 aluminium alloy.

The LM6 aluminium alloy with a chemical composition as listed in Table 2 was melted in the electric induction furnace and the temperature was raised to $780{ }^{\circ} \mathrm{C}$. The steel-wire mesh was placed inside the preheated die at various orientations of $(0,45 \text { and } 90)^{\circ}$. The melt was degassed with hexachloroethane tablets and a measured quantity of the LM6 aluminium alloy was poured into the preheated die, which was maintained at a temperature of $225{ }^{\circ} \mathrm{C}$. A squeeze pressure of $125 \mathrm{MPa}$ was applied during the solidification and the component was ejected subsequently, using an ejector pin. Cylindrical castings with a $60-\mathrm{mm}$ diameter and 75-mm height, as shown in Figure 3, were prepared using this process.

Samples were prepared to investigate the microstructure and micro-hardness. The microstructure of the



Figure 2: Modified universal testing machine for squeeze casting composites was analysed using an image analyser. The micro-hardness of the composites was measured using a micro-hardness tester (Model 3212 and Zwick hardness tester, USA) with a load of $0.2 \mathrm{~kg}$. Tensile specimens were prepared using a wire-cut electrical discharge machine as per ASTM E8 standard, with a gauge length of $25 \mathrm{~mm}$, width and thickness of $6 \mathrm{~mm}$. The specimens were tested using an extensometer (Model TECSOL, TMC Engineering, India) and the average values of two tensile-test readings are shown in Table 3.

\section{RESULTS AND DISCUSSION}

\subsection{Microstructure}

Microscopic observations of the matrix and composites are shown in Figure 4a to $\mathbf{4 d}$. It is observed that the steel-wire mesh was reinforced in the aluminium alloy, showing better interface bonding between the steel wire and aluminium due to the presence of the zinc coating on the steel wires. The squeeze pressure during the solidification process made the aluminium matrix denser resulting in a fine microstructure.

\subsection{Hardness}

The hardness of the composites was observed at four locations in a sample and the average of hardness values was considered to plot the graph. A variation in the hardness of the composites against the distance between the steel wire and the matrix is depicted in Figure 5. It can be seen that the hardness of the composites increased with the increasing distance from the matrix to the steel wire. This is due to the incorporation of the zinc-coated steel-wire mesh into the aluminium matrix. Zinc dissolves in aluminium leading to solid-solution strengthening, which improves the interfacial bonding between aluminium and the steel wire that resists plastic deformation. Also, the squeeze pressure minimises the porosity, leading to a fine microstructure that also contributes to the improvement of the hardness. The maximum hardness values of $(135,96$ and 61) VHN were observed for the steel wire, the interface between the steel wire and the matrix and the aluminium matrix, respectively.

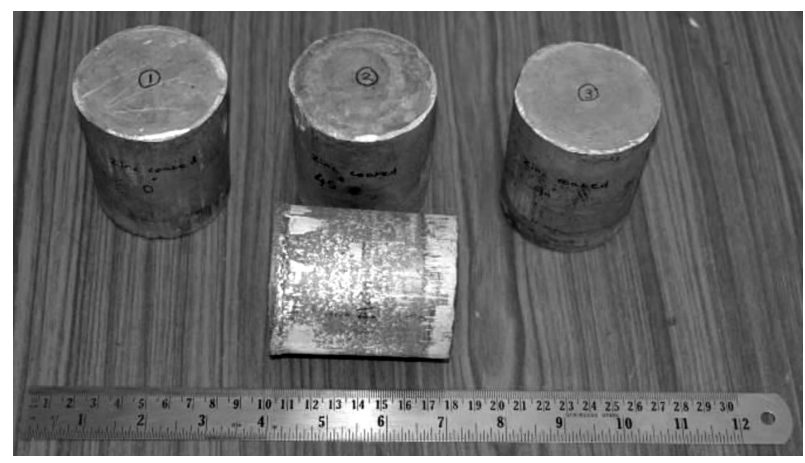

Figure 3: Sample castings prepared with squeeze casting 

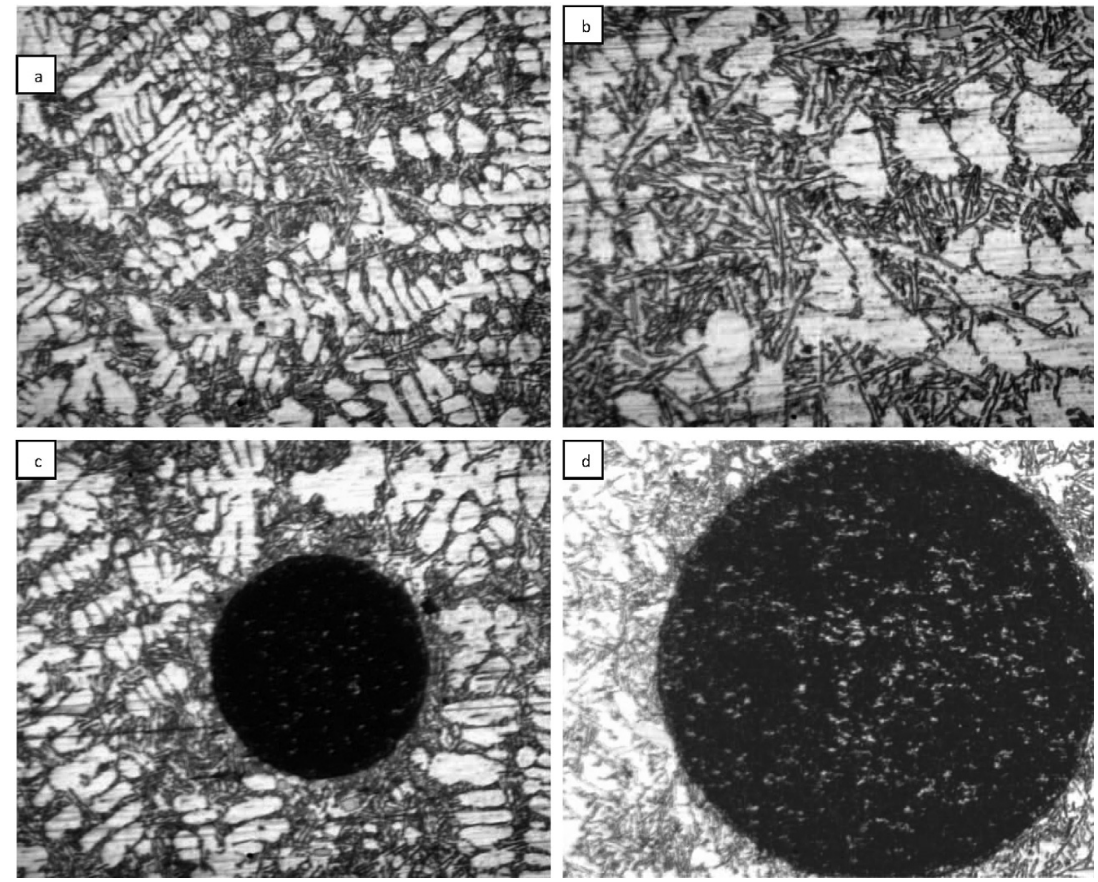

Figure 4: Optical micrographs of LM6 aluminium alloy reinforced with zinc-coated steel-wire mesh: a) LM6 matrix at 50x, b) LM6 matrix at $100 \times$, c) LM6 matrix with a steel wire at 50x, d) LM6 matrix with a steel wire at 100x

\subsection{Tensile strength}

The tensile-strength values for the LM6 alloy and the composites are given in Table 3. The variation in the tensile strength of the composites against the orientation of the zinc-coated steel-wire mesh is shown in Figure 6. It is observed that the tensile strength of the composites increases with the increasing angle of orientation. The steel-wire mesh at the orientation of $90^{\circ}$ allows the highest tensile strength compared to the $0^{\circ}$ and $45^{\circ}$ orientations. This is due to the reinforcement of the steel-wire mesh parallel to the loading condition; the matrix transmits the load to the steel-wire mesh, allowing a high tensile strength of $164 \mathrm{MPa}$. However, the steel-wire mesh at the orientations of $0^{\circ}$ and $45^{\circ}$ allows a low tensile strength compared to the matrix. This is due

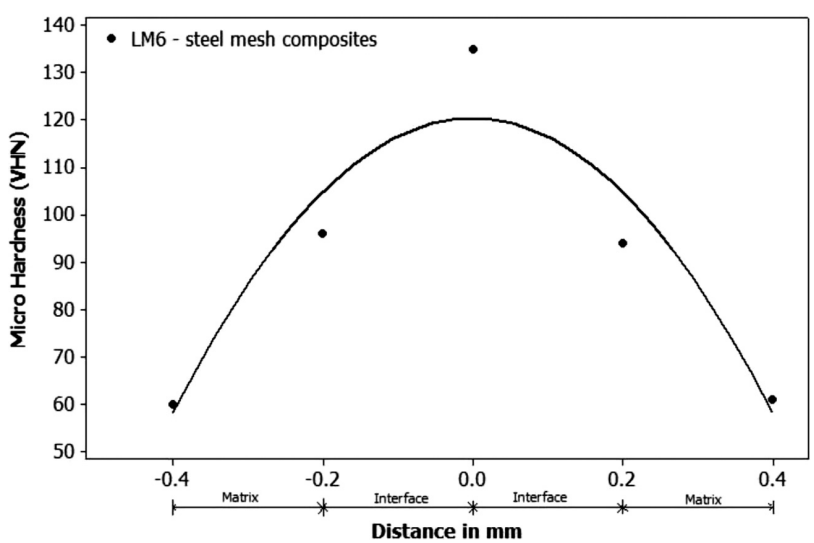

Figure 5: Variation of micro-hardness with the distance between the matrix and steel wire to the micropores at the interface of aluminium and the steel wire, which act as crack-nucleating points and reduce the tensile strength of the composites.

Table 3: Mechanical properties of the matrix and the composite with various angles of steel-wire-mesh orientation

\begin{tabular}{|c|c|c|}
\hline Specimen code & $\begin{array}{c}\text { Tensile strength } \\
(\mathrm{MPa})\end{array}$ & $\%$ of elongation \\
\hline $\mathrm{LM6}$ & 148 & 23.75 \\
\hline $\mathrm{LM6}-\mathrm{ZnFe}-0^{\circ}$ & 119 & 14.7 \\
\hline $\mathrm{LM} 6-\mathrm{ZnFe}-45^{\circ}$ & 141 & 15.95 \\
\hline $\mathrm{LM} 6-\mathrm{ZnFe}-90^{\circ}$ & 164 & 17.35 \\
\hline
\end{tabular}

The ductility of the composites was measured based on the percentage of elongation as shown in Table 3. It is observed that the ductility of a composite decreases with the incorporation of the steel-wire mesh into the



Figure 6: Variation of the tensile strength of the composites due to the angle of orientation 

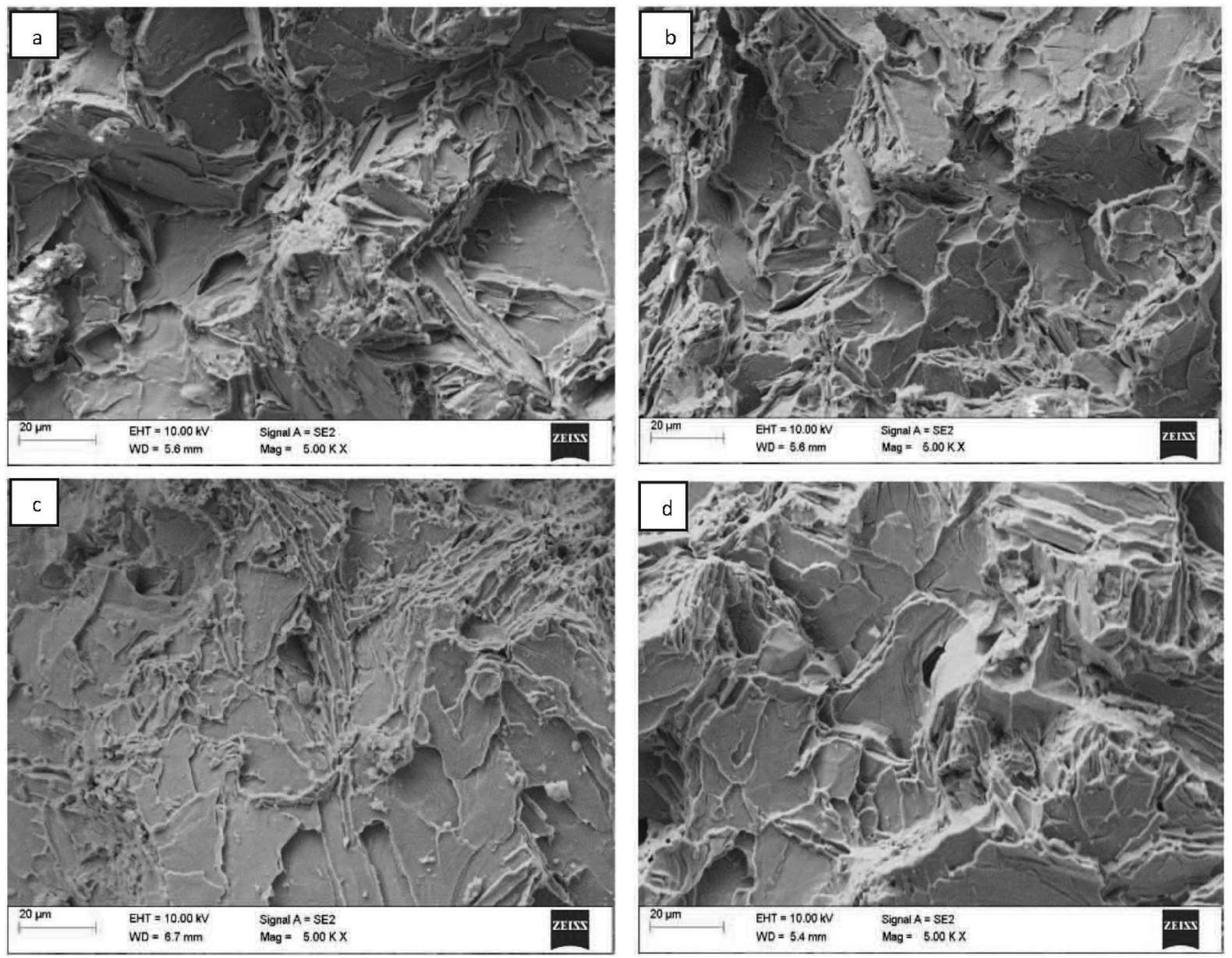

Figure 7: FESEM photographs of the fracture surfaces of different composites: a) LM6 matrix, b) $\mathrm{LM} 6-\mathrm{ZnFe}-0^{\circ}$, c) LM6-ZnFe - 45 ${ }^{\circ}$, d) $\mathrm{LM} 6-\mathrm{ZnFe}-90^{\circ}$

aluminium alloy. The presence of micropores at the interface of aluminium and steel wire, the crack initiation at the interface and the propagation cause the failure of the composites.

\subsection{Fracture surface}

Figure 7 shows photographs of the fracture surfaces of the LM6 matrix and composites with orientations of $(0,45 \text { and } 90)^{\circ}$. A ductile fracture was observed in the matrix and composites during the tensile test. Figure 7a depicts the fracture surface of the LM6 matrix and the fracture occurs due to a dimple formation. Figures $7 \mathbf{b}$ to 7c show the fracture surfaces of the zinc-coated steelwire mesh at the orientations of $0^{\circ}$ and $45^{\circ}$, respectively. The fracture mechanism is dominated by the steel wire pull-out due to the presence of the micropores and voids at the interface of steel and aluminium and dimple formation. The fracture surface of the zinc-coated steel-wire mesh at the orientation of $90^{\circ}$ is shown in Figure 7d. Fracture is dominated by the steel wire pull-out, resulting from a broken steel wire rather than a dimple formation. R. Baron et al. ${ }^{8}$ and R. B. Bhagat ${ }^{9}$ and D. Mandal et al. ${ }^{11}$ worked with stainless-steel wire/steel preform/steel fibres reinforced in an aluminium matrix by squeeze casting and stir casting and observed that a crack was initiated at the interface of the reinforcement and the matrix causing a fracture of the composite upon propagation.

\section{CONCLUSIONS}

Zinc-coated steel-wire mesh was reinforced at different orientations of $(0,45 \text { and } 90)^{\circ}$ in the LM6 aluminium alloy by squeeze casting. The microstructures of the composites were analysed and the mechanical properties, viz., the hardness, tensile strength, ductility were investigated. From the above investigation, the following conclusions are made:

- The microstructures of the composites showed good interface bonding between aluminium and steel wire due to zinc coating of the steel wires.

- The hardness of the composites increased with the increasing distance from the matrix to the steel wire. The maximum hardness values of 135 VHN and 96 VHN were observed for the steel wire and the interface. 


\section{S. J. S. CHELLADURAI et al.: INVESTIGATION OF THE MECHANICAL PROPERTIES OF A SQUEEZE-CAST LM6 ...}

- The tensile strength of the composites increased with the orientation of the reinforcement. The maximum tensile strength of $164 \mathrm{MPa}$ was observed for the steel-wire mesh at the angle of $90^{\circ}$ orientation. The ductility of the composites decreased with the incorporation of steel-wire mesh into the aluminium alloy.

- The fracture surfaces of the composites caused steel-wire pull-outs and broken wires; and a dimple formation was observed in the matrix.

- This developed composite may be considered as a potential candidate to be used as a structural member in automobile, aerospace and marine applications because of its advantageous hardness and tensile strength.

\section{REFERENCES}

${ }^{1}$ S. D. Saravanan, M. S. Kumar, Effect of mechanical properties on rice husk ash reinforced aluminum alloy (AlSi10Mg) matrix composites, Procedia Engineering, 64 (2013), 1505-1513, doi:10.1016/ j.proeng.2013.09.232

${ }^{2}$ M. K. Akbari, O. Mirzaee, H. R. Baharvandi, Fabrication and study on mechanical properties and fracture behavior of nanometric $\mathrm{A} 12 \mathrm{O} 3$ particle-reinforced A356 composites focusing on the parameters of vortex method, Materials \& Design, 46 (2013), 199-205, doi:10.1016/j.matdes.2012.10.008

${ }^{3}$ J. D. R. Selvam, D. S. Robinson Smart, I. Dinaharan, Microstructure and some mechanical properties of fly ash particulate reinforced AA6061 aluminum alloy composites prepared by compocasting, Materials \& Design, 49 (2013), 28-34, doi:10.1016/j.matdes. 2013.01.053

${ }^{4}$ S. A. Sajjadi, H. R. Ezatpour, M. T. Parizi, Comparison of microstructure and mechanical properties of A356 aluminum alloy/Al2O3 composites fabricated by stir and compo-casting processes, Materials \& Design, 34 (2012), 106-111, doi:10.1016/j.matdes.2011.07.037

${ }^{5}$ A. Mazahery, M. O. Shabani, Mechanical properties of squeeze-cast A356 composites reinforced with B4C particulates, Journal of Materials Engineering and Performance, 21 (2012) 2, 247-252, doi:10.1007/s11665-011-9867-6

${ }^{6}$ A. Mazahery, M. O. Shabani, Characterization of cast A356 alloy reinforced with nano $\mathrm{SiC}$ composites, Transactions of Nonferrous Metals Society of China, 22 (2012) 2, 275-280, doi:10.1016/S10036326(11)61171-0

${ }^{7}$ S. Sulaiman, M. Sayuti, R. Samin, Mechanical properties of the as-cast quartz particulate reinforced LM6 alloy matrix composites, Journal of Materials Processing Technology, 201 (2007) 1-3, 731-735, doi:10.1016/j.jmatprotec.2007.11.221

${ }^{8}$ S. V. Prasad, R. Asthana, Aluminum metal-matrix composites for automotive applications: Tribological considerations, Tribology Letters, 17 (2004) 3, 445-453, doi:10.1023/B:TRIL.0000044492. 91991.f3

${ }^{9}$ Z. Ahmad, Mechanical behavior and fabrication characteristics of aluminum metal matrix composite alloys, Journal of Reinforced Plastics and Composites, 20 (2001) 11, 921-944, doi:10.1177/ 073168401772678896

${ }^{10}$ P. Sharma, K. Paliwal, R. Kumar, S. Sharma, A study on wear behaviour of A1/6101/graphite composites, Journal of Asian Ceramic Societies, 5 (2017) 1, 42-48, doi:10.1016/j.jascer.2016.12.007

${ }^{11}$ V. R. Rao, N. Ramanaiah, M. M. M. Sarcar, Dry sliding wear behavior of TiC - AA7075 metal matrix composites, International Journal of Applied Science and Engineering, 14 (2016) 1, 27-37
${ }^{12}$ L. Francis Xavier, P. Suresh, Wear behavior of aluminium metal matrix composite prepared from industrial waste, The Scientific World Journal, 2016 (2016), 1-8, doi: 10.1155/2016/6538345

${ }^{13}$ G. Karthikeyan, G. R. Jinu, Dry sliding wear behaviour of stir cast LM 25 / ZrO2 metal matrix composites, Transactions of Femina, 39, (2015) 4, 89-98

${ }^{14}$ G. B. V. Kumar, R. Pramod, Influence of WC particulate reinforcement on the mechanical properties and sliding wear of Al6061 alloys, Applied Mechanics and Materials, 813-814 (2015), 67-73, doi:10.4028/www.scientific.net/AMM.813-814.67

${ }^{15}$ A. Canakci, F. Arslan, Abrasive wear behaviour of B4C particle reinforced A12024 MMCs, The International Journal of Advanced Manufacturing Technology, 63 (2012) 5-8, 785-795, doi:10.1007/ s00170-012-3931-8

${ }^{16}$ G. B. V. Kumar, N. Selvaraj, Mechanical and dry sliding wear behavior of A17075 alloy-reinforced with SiC particles, Journal of Composite Materials, 46 (2012) 10, 1201-09, doi:10.1177/ 0021998311414948

${ }^{17}$ J. B. Rao, D. V. Rao, K. S. Prasad, N. R. M. R. Bhargava, Dry sliding wear behaviour of fly ash particles reinforced AA 2024 composites, Materials Science-Poland, 30 (2012) 3, 204-211, doi:10.2478/ s13536-012-0026-Z

${ }^{18}$ S. Seshan, A. Guruprasad, M. Prabha, A. Sudhakar, Fibre-reinforced metal matrix composites - a review, Journal of Indian Institute of Science, 76 (1996), 1-14

${ }^{19}$ H. B. M. Rajan, S. Ramabalan, I. Dinaharan, S. J. Vijay, Synthesis and characterization of in situ formed titanium diboride particulate reinforced AA7075 aluminum alloy cast composites, Materials and Design, 44 (2013), 438-445, doi:10.1016/j.matdes.2012.08.008

${ }^{20}$ R. Soundararajan, A. Ramesh, S. Sivasankaran, M. Vignesh, Modeling and analysis of mechanical properties of aluminium alloy (A413) reinforced with boron carbide (B4C) processed through squeeze casting process using artificial neural network model and statistical technique, Materials Today Proceedings, 4 (2017) 2, 2008-2030, doi:10.1016/j.matpr.2017.02.047

${ }^{21}$ R. Soundararajan, A. Ramesh, N. Mohanraj, N. Parthasarathi, An investigation of material removal rate and surface roughness of squeeze casted A413 alloy on WEDM by multi response optimization using RSM, Journal of Alloys and Compounds, 685 (2016), 533-545, doi:10.1016/j.jallcom.2016.05.292

${ }^{22}$ R. Soundararajan, A. Ramesh, S. Sivasankaran, A. Sathishkumar, Modeling and analysis of mechanical properties of aluminium alloy (A413) processed through squeeze casting route using artificial neural network model and statistical technique, Advances in Materials Science and Engineering, 2015 (2015), 1-16, doi:10.1155/2015/714762

${ }^{23}$ P. Senthil, K. S. Amirthagadeswaran, Optimization of squeeze casting parameters for non symmetrical AC2A aluminium alloy castings through Taguchi method, Journal of Mechanical Science and Technology, 26, (2012) 4, 1141-1147, doi:10.1007/s12206-0120215-Z

${ }^{24}$ Q. Zhang, M. Masoumi, H. Hu, Influence of applied pressure on tensile behaviour and microstructure of squeeze cast Mg alloy AM50 with Ca addition, Journal of Materials Engineering and Performance, 21 (2012) 1, 38-46, doi:10.1007/s11665-010-9810-2

${ }^{25}$ S. Koksal, F. Ficici, R. Kayikci, O. Savas, Experimental optimization of dry sliding wear behavior of in situ AlB2/Al composite based on Taguchi's method, Materials \& Design, 42 (2012), 124-130, doi:10.1016/j.matdes.2012.05.048

${ }^{26}$ C. S. Goh, K. S. Soh, P. H. Oon, B. W. Chua, Effect of squeeze casting parameters on the mechanical properties of AZ91-Ca Mg alloys, Materials \& Design, 31 (2010) 1, S50-S53, doi:10.1016/ j.matdes.2009.11.039

${ }^{27}$ R. Baron, J. Wert, D. Gerard, F. Wawner, The processing and characterization of sintered metal-reinforced aluminium matrix composites, Journal of Materials Science, 32 (1997) 24, 6435-6445 


\section{S. J. S. CHELLADURAI et al.: INVESTIGATION OF THE MECHANICAL PROPERTIES OF A SQUEEZE-CAST LM6 ...}

${ }^{28}$ R. B. Bhagat, High pressure squeeze casting of stainless steel wire reinforced aluminium matrix composites, Composites, 19 (1988) 5, 393-399, doi:10.1016/0010-4361(88)90127-9

${ }^{29}$ S. Pourhosseini, H. Beygi, S. A. Sajjadi, Effect of metal coating of reinforcements on the microstructure and mechanical properties of Al-Al2O3 nanocomposites, Materials Science and Technology, (2017), 1-8, doi:10.1080/02670836.2017.1366708

${ }^{30}$ E. Hajjari, M. Divandari, H. Arabi, Effect of applied pressure and nickel coating on microstructural development in continuous carbon fiber-reinforced aluminum composites fabricated by squeeze casting, Materials and Manufacturing Processes, 26 (2011), 599-603, doi:10.1080/10426910903447311

${ }^{31}$ E. J. Guo, H. Yue, W. Fei, L. Wang, Tensile properties of ZnO- and $\mathrm{ZnAl2O} 4$ - coated aluminum borate whiskers reinforced aluminum composites at elevated temperatures, Journal of Composite Materials, 46 (2011) 12, 1475-1481, doi:10.1177/ 0021998311421041

${ }^{32}$ E. Hajjari, M. Divandari, A. R. Mirhabibi, The effect of applied pressure on fracture surface and tensile properties of nickel coated continuous carbon fiber reinforced aluminum composites fabricated by squeeze casting, Materials \& Design, 31 (2010) 5, 2381-2386, doi:10.1016/j.matdes.2009.11.067

${ }^{33}$ B. B. Singh, M. Balasubramanian, Processing and properties of copper-coated carbon fibre reinforced aluminium alloy composites, Journal of Materials Processing Technology, 209 (2009) 4, 2104-2110, doi:10.1016/j.jmatprotec.2008.05.002

${ }^{34}$ Y.Tang, L. Liu, W. Li, B. Shen, W. Hu, Interface characteristics and mechanical properties of short carbon fibers/Al composites with different coatings, Applied Surface Science, 255 (2009) 8, 4393-4400, doi:10.1016/j.apsusc.2008.10.124

${ }^{35}$ C. S. Ramesh, R. Keshavamurthy, B. H. Channabasappa, A. Ahmed, Microstructure and mechanical properties of Ni-P coated Si3N4 reinforced A16061 composites, Materials Science and Engineering: A, 502 (2009) 1-2, 99-106, doi:10.1016/j.msea.2008.10.012

${ }^{36}$ L. Xia, B. Jia, J. Zeng, J. Xu, Wear and mechanical properties of carbon fiber reinforced copper alloy composites, Materials Characterization, 60 (2009) 5, 363-369, doi:10.4028/www.scientific.net/ KEM.474-476.1605

${ }^{37}$ A. Urena, J. Rams, M. Campo, M. Sanchez, Effect of reinforcement coatings on the dry sliding wear behaviour of aluminium/SiC particles/carbon fibres hybrid composites, Wear 266 (2009) 11-12, 1128-1136, doi:10.1016/j.wear.2009.03.016

${ }^{38} \mathrm{C}$. Tekmen, U. Cocen, Squeeze casting of Ni coated $\mathrm{SiC}$ particle reinforced Al based composite, Journal of Composite Materials, 42 (2008) 13, 1271-1279, doi:10.1177/0021998308092195

${ }^{39}$ D. Mandal, B. K. Dutta, S.C. Panigrahi, Effect of copper and nickel coating on short steel fiber reinforcement on microstructure and mechanical properties of aluminium matrix composites, Materials Science and Engineering: A, 492 (2008) 1-2, 346-352. doi:10.1016/ j.msea.2008.03.031

${ }^{40}$ V.V. Ganesh, C. K. Lee, M. Gupta, Enhancing the tensile modulus and strength of an aluminum alloy using interconnected reinforcement methodology, Materials Science and Engineering: A, 333 (2002) 1-2, 193-198. doi:10.1016/S0921-5093(01)01831-7 